\title{
How Business Ethics Can Enhance the Brand Image in the Healthcare Sector - A Case Study of Evercare Hospital in Bangladesh
}

\author{
Nazmun Nahar Emma and Sharjana Alam Shaily
}

\begin{abstract}
The healthcare sector is one of the most important industries in the economy of a country. Ethical practices in this sector are crucial for organizations to follow. The main aim of this paper is to analyze and evaluate the impact of business ethics on the brand image in the healthcare sector. The authors have chosen Evercare Hospital which is situated in Bangladesh as their case to carry out the research for this paper. Primary data for this research has been collected from a sample size of 110 respondents, which includes both employees and customers of Evercare Hospital, with the help of a structured set of survey questions. The data collected has been analyzed using SPSS as per the purposes of the current research. The research has revealed that carrying out ethical practices has a positive impact on the brand image of a company. Therefore, Evercare Hospital needs to focus on its ethical practices and carry them out properly to further strengthen its brand image.
\end{abstract}

Index Terms - Brand Image, Ethical Practice, Evercare Hospital, Healthcare Sector.

\section{INTRODUCTION}

The healthcare sector has currently become one of the most competitive sectors in every country mainly due to the requirement of ethics for a stronger brand image [1]. It is one of the most important industries in an economy as medication and healthcare are one of the basic rights of every citizen in the country. This is one of the only sectors that have experienced great strength and consistency in the demand for its services over time [2]. It has been noted that the healthcare industry has been growing even faster than the economy itself in certain countries, as the population and the living standards of people are both growing resulting in this industry's growth [3].

To maintain the quality of services hospitals, provide to their consumers, many of them have chosen to carry out ethical practices within their operations so that consumer trust is strengthened followed by the brand image [4].

In Dhaka, Bangladesh, Evercare Hospital is one of the best hospitals that aims to provide a superior quality of international level healthcare to the people taking services from them. They make use of advanced technology and expert employees to achieve this aim.
Business ethics are a set of morale that teaches businesses the difference between what is right and what is not. It helps businesses to form and operate their corporate framework in such a way that it is easily made acceptable in society [5]. Business ethics may vary from business to business, and it is usually led by legal terms. However, there is no specific way or rule for following business ethics. Therefore, all businesses do not need to create and follow a specific code of ethics [6]. Businesses can create their code of ethics as per their requirement or the nature of the business itself. Ethical businesses consider the welfare of the society besides their profits, before starting their operations. Certain businesses also carry out their ethical practices in the form of Corporate Social Responsibility (CSR).

Brand image is a factor, which is completely under the consumers' control. This is because the brand image is the standing opinion of the consumers about a brand [7]. The brand image consists of varying opinions from consumers - both positive and negative. The positive or negative viewpoints of consumers mostly depend on the kinds of activities the business is carrying out. Brand image shows the location of certain brands in the market, in terms of consumer opinions and preferences. Brand image must highlight the mission and vision of a brand to all its consumers [8].

\section{A. Research Objectives}

The main yet general objective of this paper is to analyze the impact of business ethics on brand image, but the authors have also considered the following research objectives:

1. To analyze the importance of moral practices on the brand image of Evercare.

2. To provide a broad view of the serious aspects of ethical business, affecting the brand image.

3. To review the effect of ethical practice to encourage more customers to take more services from Evercare.

\section{B. Background of Evercare Hospital}

Evercare Hospital is a part of the Evercare Group, which is an assimilated platform of healthcare delivery [9]. This company has its operations in developing markets in countries of Africa and South Asia. The company has operated in 
countries including India, Pakistan, Bangladesh, Nigeria, and Kenya. This company helps different communities by refining healthcare and leveraging technology and incorporation so that they can ensure superior quality of care [10].

Evercare Hospital started its operation in Bangladesh on April 1, 2020. The hospital was previously known as Apollo Hospitals Dhaka. The hospital consists of eleven floors and has a facility of 425 beds [11]. It provides superior quality healthcare with the latest medical equipment and accommodation. The building is constructed on a plot of 4 acres, with 435,000 sq. feet floor space [12]. It was built with the assistance of the well-known architecture company Smith Group, USA. This hospital is a venture of the Evercare Group itself and CDC Group.

\section{LITERATURE REVIEW}

\section{A. Brand Image}

Brand image is the term used to describe the consumers' perspective about a particular brand and its products. According to Kotler, image is the set of concepts and views held by a person about something particular [13]. Various consumers might have various viewpoints when it comes to a brand. The brand image takes some time to progress, and businesses typically make use of reliably themed campaigns for advertising, and other approaches of promotion, to form a progressive brand image for the products and/or services they offer [14].

The brand image of a product acts as a pointer, which forecasts the size of sales for that particular product. When it comes to the positive or negative perspectives of consumers considering a product, it completely depends on the promotional activities being carried out by the business to market their products to the target consumers.

As simple as the concept of brand image sounds, it is quite a challenge for businesses to create a strong and positive brand image for themselves. This is because businesses have no control over what consumers think of their brand. As different consumers will have different perspectives about the products a brand has to offer, creating a positive brand image is one of the biggest challenges a business is likely to face [15].

\section{B. Business Ethics}

Business ethics acts as an indicator for businesses on how they should act in situations where there are several dilemmas or involvement of controversies. Ethics provides guidelines to businesses on how they should conduct their operations and overall transactions.

Business ethics makes sure that there is a certain amount of trust between the business itself and its consumers. When businesses claim that they are "acting ethically", that means they can differentiate between what is right and what is wrong [16].

Due to a rise in globalization and communication in the corporate world, business ethics has become a trend for every brand nowadays. Businesses are being able to set an example to other businesses by being ethical. They can also set up a standard within their organization, to monitor and control their behavior, as well as motivate employees to follow those standards. Every business must have the existence of ethics in their organization. The existence of ethics and principles not only helps businesses in terms of their customer base but also ensures that businesses are operating within the limits of the law and that they are not being involved in criminal or illegal activities [17].

If businesses are ethical, consumers are likely to trust them more. Once businesses can gain their consumer trust, they are ensured that consumers will prefer them over their rivals [18].

The relationship between business ethics and brand image is quite crucial, as most businesses sometimes find it quite difficult to maintain ethics and a strong brand image at the same time [19]. However, the world we live in today values business with morals. Therefore, business ethics is one of the most important elements for businesses today [20].

\section{CONCEPTUAL FRAMEWORK AND METHODOLOGY A. Conceptual Framework}

The conceptual framework, which leads to the complete developments of this study, has been created emphasizing on the objectives of the research. It involves the two variables independent variable (ethical leadership, CSR activities, employee health, and safety, \& transparent stakeholder communication), and dependent variable (brand image).

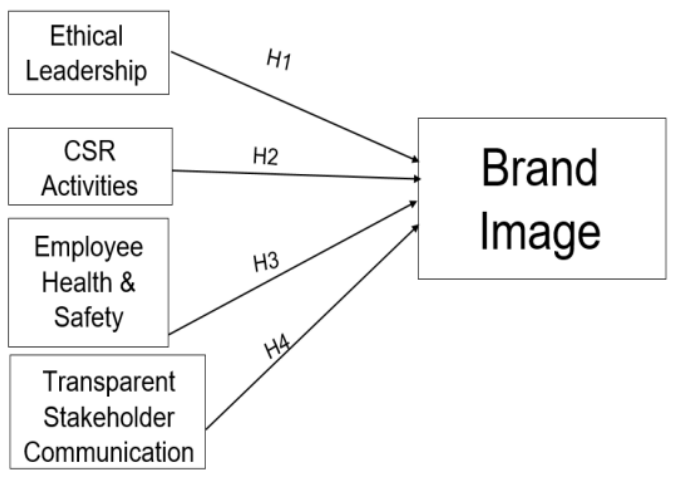

Fig. 1. Conceptual Framework.

According to studies conducted previously, it was found that businesses practicing ethics throughout their organizations in different forms have a positive and strong impact on their brand image.

The authors have proposed the following four hypotheses that are to be tested for this study:

Hypotheses that have a direct impact

H1: Ethical leadership has a positive and significant impact on brand image.

H2: CSR activities have a positive impact on brand image.

H3: The level of standard for health and safety at the workplace has a strong impact on brand image.

H4: Transparency when communicating with stakeholders has a significant impact on the brand image of a company. 


\section{B. Research Methodology}

Questionnaire Design and Scale: The questionnaire developed for this study has two sections. One section is for the consumers taking service from Evercare, and the other is for the employees that work for the company.

The authors have developed questions based on the pricing, service quality, billing information, communication transparency, and timeliness in attending their consumers - for the consumers of the hospital.

While for the employees, the authors have developed a set of questions based on factors such as the reliability of the medicines, transparent communication with consumers, the basis of their brand image, safety standards, and confidentiality of their patients' medical information.

The questionnaires for this study are structured using the Likert Scale, where the respondents are given five points strongly agree, agree, no comments, disagree and strongly disagree.

The authors have made use of both qualitative and quantitative methods for this research - focusing on both, numerical data as well as several fundamental details.

\section{Data Collection Techniques}

The authors have used both primary and secondary data to conduct this study. Primary data was extracted using the questionnaire and by conducting interviews with some of the employees of the organization, and secondary data was obtained using various sources such as literature on the topic, journals, articles, magazines, textbooks, and several credible online sources.

Trained individuals collected the primary data. They provided the questionnaires to the consumers of the hospital inside the hospital's waiting area, cafeteria, and the entrance. While the employees were provided the questionnaires in the hospital itself.

\section{DATA ANALYSIS}

The Statistical Package for the Social Sciences (SPSS) software has been used by the authors to analyze the data that was collected from the respondents of the questionnaire. The authors have also provided several descriptive statistics to present that data.

After the authors had received all the answers for the questions present in the questionnaire, only the usable copies were considered for conducting further analysis, and the incomplete ones were rejected. SPSS software was used for this analysis of the study.

\section{A. H1: Ethical Leadership Has a Positive and Significant Impact on Brand Image}

\begin{tabular}{ccccc}
\multicolumn{5}{c}{ TABLE I: MoDEL SUMMARY } \\
\hline Model & $\mathrm{R}$ & R Square & $\begin{array}{c}\text { Adjusted R } \\
\text { Square }\end{array}$ & $\begin{array}{c}\text { Std. Error of the } \\
\text { Estimate }\end{array}$ \\
\hline 1 & $.644^{\mathrm{a}}$ & .415 & .367 & 1.11689 \\
\hline
\end{tabular}

a. Predictors: (Constant), Ethical Leadership, Ethical Grounds, Ethical Doctors.
Taking the model summary into consideration, it is evident that the regression is relatively strong as presented by the coefficient of $\mathrm{R}=0.644$ or $64.4 \%$. Additionally, the R-square value indicates that the connection between the independent and dependent variables is 0.415 or $41.5 \%$. This further explains the strength of the relationship between the two variables.

TABLE II: ANOVA ${ }^{\mathrm{a}}$

\begin{tabular}{ccccccc}
\hline \multirow{2}{*}{ Model } & $\begin{array}{c}\text { Sum of } \\
\text { Squares }\end{array}$ & df & $\begin{array}{c}\text { Mean } \\
\text { Square }\end{array}$ & F & Sig. \\
\hline \multirow{4}{*}{1} & Regression & 32.723 & 3 & 10.908 & 8.744 & $.000^{\mathrm{b}}$ \\
& Residual & 46.155 & 37 & 1.247 & & \\
& Total & 78.878 & 40 & & & \\
\hline
\end{tabular}

a. Dependent Variable: Brand Image.

b. Predictors: (Constant), Ethical Leadership, Ethical Grounds, Ethical Doctors.

In the ANOVA table, the p-value of Sig- 0.00 further confirms how rational the regression model is and shows it as exceptionally significant at $0 \%$ level of confidence. Furthermore, the F-test is ignored as it shows the approval of the null hypothesis.

TABLE III: COEFFICIENTS ${ }^{\mathrm{a}}$

\begin{tabular}{|c|c|c|c|c|c|c|}
\hline & \multirow[t]{2}{*}{ Model } & \multicolumn{2}{|c|}{$\begin{array}{c}\text { Unstandardized } \\
\text { Coefficients }\end{array}$} & \multirow{2}{*}{$\begin{array}{c}\text { Standardized } \\
\text { Coefficients }\end{array}$} & \multirow[t]{2}{*}{$\mathrm{t}$} & \multirow[t]{2}{*}{ Sig. } \\
\hline & & B & Std. Error & & & \\
\hline \multirow{4}{*}{1} & (Constant) & 3.475 & .652 & & 5.327 & .000 \\
\hline & Ethical Doctors & -.475 & .129 & -.499 & -3.687 & .001 \\
\hline & Ethical Grounds & -.127 & .137 & -.118 & -.923 & .362 \\
\hline & Ethical Leadership & .576 & .136 & .562 & 4.232 & .000 \\
\hline
\end{tabular}

a. Dependent Variable: Brand Image.

Considering the $\mathrm{p}$-values above $(\mathrm{Sig}=0.001,0.362$, and 0.000 ), the amount of significance between the variables tested is strong. Moreover, the coefficient $\mathrm{B}=0.562$ recommends an extraordinarily strong and constructive association between ethical leadership and brand image.

All three variables have a strong relationship with the brand image, but ethical leadership, and ethical doctors have the strongest relationship (Ethical leadership $=0.000$ and Ethical doctors $=0.001)$. This hypothesis is being supported very intensely.

\section{B. H2: CSR Activities Have a Positive Impact on Brand Image}

TABLE IV: MODEL SUMMARY

\begin{tabular}{|c|c|c|c|c|}
\hline Model & $\mathrm{R}$ & R Square & Adjusted R Square & $\begin{array}{l}\text { Std. Error of the } \\
\text { Estimate }\end{array}$ \\
\hline 1 & $.713^{\mathrm{a}}$ & .507 & .583 & .52253 \\
\hline
\end{tabular}

Taking the model summary into consideration, it is evident that the regression is strong, as the value of $\mathrm{R}(\mathrm{R}=0.713)$ shows. Furthermore, the adjusted R-square value of 0.583 holds back the mentioned variables. The connection between the 
independent and dependent variables is $50.7 \%$, as shown by Rsquare $=0.507$.

\begin{tabular}{ccccccc}
\multicolumn{7}{c}{ TABLE V: ANOVA $^{\mathrm{a}}$} \\
\hline \multirow{2}{*}{ Model } & $\begin{array}{c}\text { Sum of } \\
\text { Squares }\end{array}$ & df & $\begin{array}{c}\text { Mean } \\
\text { Square }\end{array}$ & F & Sig. \\
\hline \multirow{2}{*}{1} & Regression & 12.413 & 2 & 6.206 & 3.548 & $.001^{\text {b }}$ \\
& Residual & 66.465 & 38 & 1.749 & & \\
& Total & 78.878 & 40 & & & \\
\hline
\end{tabular}

a. Dependent Variable: Brand Image.

b. Predictors: (Constant), CSR, CSR Activities.

In the ANOVA table, the p-value of Sig-0.001 confirms the rationality of the regression model and recommends that it is greatly significant, at $1 \%$ level of confidence.

TABLE VI: COEFFICIENTS ${ }^{\mathrm{a}}$

\begin{tabular}{|c|c|c|c|c|c|c|}
\hline & \multirow[t]{2}{*}{ Model } & \multicolumn{2}{|c|}{$\begin{array}{l}\text { Unstandardized } \\
\text { Coefficients }\end{array}$} & \multirow{2}{*}{$\begin{array}{c}\begin{array}{r}\text { Standardized } \\
\text { Coefficients }\end{array} \\
\text { Beta }\end{array}$} & \multirow[t]{2}{*}{$\mathrm{t}$} & \multirow[t]{2}{*}{ Sig. } \\
\hline & & B & Std. Error & & & \\
\hline \multirow{3}{*}{1} & (Constant) & 4.598 & .712 & & 6.462 & .000 \\
\hline & CSR & .105 & .143 & .719 & .734 & .001 \\
\hline & $\begin{array}{c}\text { CSR } \\
\text { (Ethical } \\
\text { Pledges) }\end{array}$ & -.406 & .158 & -.383 & -2.573 & .014 \\
\hline
\end{tabular}

a. Dependent Variable: Brand Image.

The p-values above ( $\mathrm{Sig}=0.001$, and 0.014) show that the amount of significance among the variables are strong to an extent. It should be noted that CSR activities have a stronger effect on brand image, than Ethical Pledges. Moreover, the coefficient, $\mathrm{B}=0.719$ recommends that there is a very strong association between the dependent and independent variables. This hypothesis is being supported very strongly.

C. H3: The Level of Standard for Health and Safety at the Workplace Has a Strong Impact on Brand Image TABLE VII: MODEL SUMMARY

\begin{tabular}{ccccc}
\hline Model & R & R Square & $\begin{array}{c}\text { Adjusted R } \\
\text { Square }\end{array}$ & $\begin{array}{c}\text { Std. Error of the } \\
\text { Estimate }\end{array}$ \\
\hline 1 & $.601^{\mathrm{a}}$ & .479 & .496 & .4824 \\
\hline
\end{tabular}

a. Predictors: (Constant), Health and Safety.

Taking the model summary into account, it can be said that the regression is very strong in this hypothesis, and this is supported by the value of $\mathrm{R}=0.601$ or $60.1 \%$. Moreover, the $\mathrm{R}-$ square value of 0.479 or $47.9 \%$ suggests that there is a $47.9 \%$ relationship between the dependent and independent variables. Therefore, there is a strong relationship between health and safety, and brand image.

TABLE VIII: ANOVA ${ }^{\mathrm{a}}$

\begin{tabular}{ccccccc}
\hline & Model & Sum of Squares & df & Mean Square & F & Sig. \\
\hline \multirow{3}{*}{1} & Regression & 12.313 & 1 & 12.313 & 1.178 & $.002^{\mathrm{b}}$ \\
& Residual & 15.565 & 49 & .463 & & \\
& Total & 27.878 & 40 & & & \\
\hline
\end{tabular}

a. Dependent Variable: Brand Image.

b. Predictors: (Constant), Health and Safety.
According to the ANOVA table, the p-value of Sig-0.004 confirms the strength of the regression model, and denotes it as quite highly significant, as the level of confidence is $2 \%$.

\begin{tabular}{|c|c|c|c|c|c|c|}
\hline \multicolumn{7}{|c|}{ TABLE IX: COEFFICIENTS ${ }^{\mathrm{a}}$} \\
\hline & \multirow[t]{2}{*}{ Model } & \multicolumn{2}{|c|}{$\begin{array}{l}\text { Unstandardized } \\
\text { Coefficients }\end{array}$} & \multirow{2}{*}{$\begin{array}{c}\begin{array}{c}\text { Standardized } \\
\text { Coefficients }\end{array} \\
\text { Beta }\end{array}$} & \multirow[t]{2}{*}{$\mathrm{t}$} & \multirow[t]{2}{*}{ Sig. } \\
\hline & & B & Std. Error & & & \\
\hline \multirow[b]{2}{*}{1} & (Constant) & 4.194 & .419 & & 8.079 & .000 \\
\hline & $\begin{array}{c}\text { Health and } \\
\text { Safety }\end{array}$ & .490 & .077 & .710 & 7.085 & .001 \\
\hline
\end{tabular}

a. Dependent Variable: Brand Image.

According to the $\mathrm{p}$-value above ( $\mathrm{Sig}=0.001$ ), the degree of significance among the variables is strong. Furthermore, the coefficient $\mathrm{B}=0.710$ suggests that there is a strong correlation between Health and Safety, and Brand Image. This hypothesis is being supported very strongly.

D. H4: Transparency When Communicating with Stakeholders Has a Significant Impact on the Brand Image of a Company

TABLE X: MODEL SUMMARY

\begin{tabular}{ccccc}
\hline Model & $\mathrm{R}$ & R Square & $\begin{array}{c}\text { Adjusted } \mathrm{R} \\
\text { Square }\end{array}$ & $\begin{array}{c}\text { Std. Error of the } \\
\text { Estimate }\end{array}$ \\
\hline 1 & $.112^{\mathrm{a}}$ & .013 & -.039 & 1.43161 \\
\hline
\end{tabular}

a. Predictors: (Constant), Transparent Stakeholder Communication, Transparent Stakeholder Communication.

Considering the model summary, it can be said that the regression is very weak; in fact, there is no relationship between transparent stakeholder communication and brand image. This is supported by the value of $\mathrm{R}=0.112$ or $11.2 \%$. Furthermore, the $\mathrm{R}$-square value of 0.013 or $1.3 \%$ suggests only a $1.3 \%$ relationship between the dependent and independent variables. The adjusted R-square shows a negative coefficient of -0.039 .

TABLE XI: ANOVA ${ }^{\mathrm{a}}$

\begin{tabular}{ccccccc}
\hline \multicolumn{2}{l}{ Model } & $\begin{array}{c}\text { Sum of } \\
\text { Squares }\end{array}$ & df & Mean Square & F & Sig. \\
\hline \multirow{2}{*}{1} & Regression & .996 & 2 & .498 & .243 & $.785^{\text {b }}$ \\
& Residual & 77.882 & 38 & 2.050 & & \\
& Total & 78.878 & 40 & & & \\
\hline
\end{tabular}

a. Dependent Variable: Brand Image.

b. Predictors: (Constant), Transparent Stakeholder Communication, Transparent Stakeholder Communication.

According to the ANOVA table, the p-value of Sig-0.785 confirms the strength of the regression model, and implies it as not significant at all, at a $78.5 \%$ level of confidence. 
TABLE XII: COEFFICIENTS ${ }^{\mathrm{a}}$

\begin{tabular}{|c|c|c|c|c|c|c|}
\hline & \multirow[t]{2}{*}{ Model } & \multicolumn{2}{|c|}{$\begin{array}{l}\text { Unstandardized } \\
\text { Coefficients }\end{array}$} & \multirow{2}{*}{$\begin{array}{c}\text { Standardized } \\
\text { Coefficients } \\
\text { Beta }\end{array}$} & \multirow[t]{2}{*}{$\mathrm{t}$} & \multirow[t]{2}{*}{ Sig. } \\
\hline & & $\mathrm{B}$ & Std. Error & & & \\
\hline \multirow{8}{*}{1} & (Constant) & 4.110 & .655 & & 6.279 & .000 \\
\hline & Transparent & & & & & \\
\hline & Stakeholder & -.066 & .162 & -.066 & -.405 & .688 \\
\hline & Communication & & & & & \\
\hline & Transparent & & & & & \\
\hline & Stakeholder & & & & & \\
\hline & $\begin{array}{l}\text { Communication } \\
\text { (Billing }\end{array}$ & -.081 & .164 & -.081 & -.495 & .624 \\
\hline & Information) & & & & & \\
\hline
\end{tabular}

a. Dependent Variable: Brand Image

According to the $\mathrm{p}$-values above ( $\mathrm{Sig}=0.688$, and 0.624$)$, the degree of significance among the variables is not strong at all. Furthermore, the coefficient $\mathrm{B}=-0.66$ suggests that there is a negative correlation between transparent stakeholder communication and brand image. This hypothesis is thus not being supported at all.

\section{DISCUSSION AND CONCLUSION}

The authors have conducted this research with the main aim of analyzing the impact of ethical practice on the brand image of a company [21]. The study has been conducted on Evercare Hospital, where the authors have surveyed 110 people, which includes both employees and consumers.

According to the conclusion reached by the authors, ethical practice is a significant component, which has a straight influence on the creation of a positive brand image for every company in the healthcare sector [22].

In today's world where consumers are very conscious about the kind of companies, they are associating themselves with, companies need to be ethical as the demand for such businesses is increasing [23]. Therefore, businesses need to be continually active when carrying out ethical functions and attain a competitive advantage throughout the entire process. Although there are several challenges involved with this practice, Evercare Hospital has been quite efficient when it comes to handling situations like this and has therefore achieved a strong brand image, followed by a large group of satisfied consumers [24].

The authors have tried to deliver a complete view of the serious factors of business ethics that affect brand image the most. The authors have also learned that factors such as ethical pricing, promotion, and marketing ethics are vital and have a direct influence on brand image. If companies can use these factors suitably, they can have a positive brand image [25].

Taking the findings from the study into consideration, it is recommended by the authors that Evercare needs to be very vigilant when it comes to the management of their ethical practices. According to the authors, there is always a scope for companies to improve, and Evercare should make use of every scope they have, to become more ethical and better.

The results from the hypotheses have made the authors recommend Evercare hospital to put their emphasis on ethical leadership, as it has the strongest correlation to the dependent variable.

Finally, the authors recommend Evercare hospital to continue being an ethical organization by improving their ethical grounds more and more so that they can act as an example for other hospitals on the significance of ethics.

\section{REFERENCES}

[1] Donaldson, T., 2019. The morals of global business (pp. 97-104). New York: Oxford University Press.

[2] Sternberg, E., 2010. Just business: Business morals in action.

[3] Jardins, J.R., 2009. An overview of business morals. NewYork: McGrawHill Higher Education.

[4] Pratley, P., 2015. The principle of business morals (Vol. 111). London: Prentice Hall.

[5] Jones, C., Parker, M. and Bos, R., 2017. For corporate morals. Routledge.

[6] Al Mahdy, H., 2009. Improving the healthcare sector of Bangladesh. IJHQA, 22(4), pp.411-416.

[7] Rahman, A., 2013. Role of corporate hospitals in the development of health care in Bangladesh. Pulse, 6(1-2), pp.4-5.

[8] Mahmud, A., Noor, F. and Nasrullah, M., 2011. Treatment administration scheme: A method to decrease treatment mistake in Apollo hospitals Dhaka. Pulse, 5(2), pp.41-47.

[9] Bowonder, B., Bansal, M. and Giridhar, A.S., 2007. A platform of telemedicine: a case study of the telemedicine project of Apollo hospitals. IJSTM, 6(3/4/5), pp.449-466.

[10] Bollineni, R., 2011. ATNF. Health International, pp.1-18.

[11] Catalan, S. and Martinez, E., 2016. The importance of corporate brand identity in business management: An application to the UK banking sector. BRQ Business Research Quarterly, 19(1), pp.3-12.

[12] Beverland, M., Lindgreen, A., Napoli, J. and Yakimova, R., 2007. Branding the business marketing offer: exploring brand attributes in business markets. Journal of Business \& Industrial Marketing.

[13] Barros, T., Martins, V. and Barandas, H.G., 2015. Corporate Brand Identity Measurement-an Internal and External Perspective. In Managing Intellectual Capital and Innovation for Sustainable and Inclusive Society: Managing Intellectual Capital and Innovation; Proceedings of the Make Learn and TIIM Joint International Conference 2015 (pp. 2277-2277). To Know Press.

[14] Tuan, L., 2012. Corporate social responsibility, leadership, and brand equity in healthcare service. Social Responsibility Journal, 8(3), pp.347362.

[15] Kim, K.H., Kim, K.S., Kim, D.Y., Kim, J.H. and Kang, S.H., 2008. Brand equity in hospital marketing. Journal of business research, 1(61), pp.7582.

[16] Hosseini, S.H. and Behboudi, L., 2017. Brand trust and image: effects on customer satisfaction. International journal of health care quality assurance, 30(7), pp.580-590.

[17] Cham, T.H., Lim, Y.M., Aik, N.C. and Tay, A.G.M., 2016. Antecedents of hospital brand image and the relationships with medical tourists' behavioral intention. International Journal of Pharmaceutical and Healthcare Marketing, 10(4), pp.412-431.

[18] Chahal, H. and Bala, M., 2012. Significant components of service brand equity in healthcare sector. International journal of health care quality assurance, 25(4), pp.343-362.

[19] Holm, S., 2017. Ethical problems in clinical practice: the ethical reasoning of health care professionals. Manchester University Press.

[20] Brown, I. and Adams, A.A., 2017. The ethical challenges of ubiquitous healthcare. International Review of Information Ethics, 8(12), pp.53-60.

[21] Weaver, K., Morse, J. and Mitcham, C., 2008. Ethical sensitivity in professional practice: concept analysis. Journal of advanced nursing, 62(5), pp.607-618.

[22] Bass, K., 2011. Health care social workers' views of ethical issues, practice, and policy in end-of-life care. Social Work in Health Care, 32(2), pp.1-22.

[23] Rushton, C.H. and Brooks, J.A., 2019. Environments that support ethical practice. New Horizons (Baltimore, Md.), 5(1), pp.20-29.

[24] Remley, T.P., 2014. Ethical, legal, and professional issues in counseling. Upper Saddle River, NJ: Pearson.

[25] Rushton, C.H., 2016. Creating a culture of ethical practice in health care delivery systems. Hastings Center Report, 46, pp. S28-S31. 